\title{
Perfusion indices revisited
}

\author{
Ahmed Hasanin ${ }^{1,2^{*}}$, Ahmed Mukhtar ${ }^{1}$ and Heba Nassar ${ }^{1}$
}

\begin{abstract}
Monitoring of tissue perfusion is an essential step in the management of acute circulatory failure. The presence of cellular dysfunction has been a basic component of shock definition even in the absence of hypotension. Monitoring of tissue perfusion includes biomarkers of global tissue perfusion and measures for assessment of perfusion in non-vital organs.

The presence of poor tissue perfusion in a shocked patient is usually associated with worse outcome. Persistently impaired perfusion despite adequate resuscitation is also associated with worse outcome. Thus, normalization of some perfusion indices has become one of the resuscitation targets in patients with septic shock.

Although the collective evidence shows the clear relation between impaired peripheral perfusion and mortality, the use of different perfusion indices as a resuscitation target needs more research.
\end{abstract}

Keywords: Perfusion indices, Lactate, Shock

\section{Background}

Monitoring of tissue perfusion is an essential step in the management of acute circulatory failure. The presence of cellular dysfunction has been a basic component of shock definition even in the absence of hypotension [1]. The ideal parameter for tissue perfusion should be rapid, non-invasive, and easily measured without the need of advanced skills. Evaluation of tissue perfusion includes clinical evaluation as well as biomarkers. Popular biomarkers of tissue perfusion such as serum lactate and central venous oxygen saturation are indicators of global tissue perfusion. Monitoring of peripheral circulation especially in non-vital organs added new insights for monitoring of tissue perfusion. Peripheral non-vital organ perfusion deteriorates earlier and improves later than vital organs. Assessment of peripheral circulation has become easier after introduction of new non-invasive devices as well as clinical scoring systems.

In this article, we provide a comprehensive updated review for all the available indices for monitoring of tissue perfusion. The advantages and disadvantages of each method will be mentioned. Thoughts for future research and gaps in literature will also be highlighted (Table 1).
* Correspondence: ahmedmohamedhasanin@gmail.com

${ }^{1}$ Anesthesia and Critical Care Medicine, Cairo University, Giza, Egypt

${ }^{2}$ Critical Care Department, El-Ameen Hospital, Taif, Kingdom of Saudi Arabia

\section{Cardiac output as a determinant of tissue perfusion}

The balance between oxygen delivery $\left(\mathrm{DO}_{2}\right)$ and oxygen consumption $\left(\mathrm{VO}_{2}\right)$ considered the mainstay of understanding the concept of tissue perfusion and the development of organ dysfunction. In a steady state, the $\mathrm{VO}_{2}$ constitutes only $25 \%$ of $\mathrm{DO}_{2}$. In a shock state, the $\mathrm{VO}_{2}$ increased out of proportion of $\mathrm{DO}_{2}$ to the point that $\mathrm{DO}_{2}$ falls below a critical threshold where the $\mathrm{VO}_{2}$ is dependent on $\mathrm{DO}_{2}$. Below that point, organ perfusion will be critically impaired and transition to anerobic metabolism will occur [2].

Because the main determinant of $\mathrm{DO}_{2}$ is the cardiac output (CO), most patients' evaluation and resuscitation strategies depend on evaluating and optimizing this parameter. Assessing $\mathrm{CO}$ is performed by invasive, minimally invasive, and non-invasive methods [3]. More recently, surviving sepsis campaign recommended the routine use of echocardiography during initial assessment of patients with septic shock [4].

\section{Markers of global perfusion \\ Lactate \\ Background}

Lactate is the end product of anerobic glycolysis [5]. Serum lactate level increases in states of cellular hypoxia or low peripheral perfusion; thus, serum lactate level is considered a surrogate of cellular perfusion [5]. 
Table 1 Perfusion indices: evidence and disadvantages

\begin{tabular}{|c|c|c|}
\hline Measure & Evidence & Disadvantages \\
\hline Lactate & Meta-analysis & $\begin{array}{l}\text { Needs blood sampling } \\
\text { Laboratory time } \\
\text { Could be elevated in other conditions than shock }\end{array}$ \\
\hline $\mathrm{ScrO}_{2}$ & $\mathrm{RCT}$ & $\begin{array}{l}\text { Needs central catheter } \\
\text { Less useful under anesthesia }\end{array}$ \\
\hline $\mathrm{P}(\mathrm{v}-\mathrm{a}) \mathrm{CO}_{2}$ & Cohort & $\begin{array}{l}\text { Needs central catheter } \\
\text { Needs blood sampling } \\
\text { Laboratory time }\end{array}$ \\
\hline Temperature gradients & Cohort & $T_{c \text {-toe }}$ is affected by hypothermia and room temperature \\
\hline LV strain & Cohort & Needs expert operator \\
\hline Skin mottling & Cohort & Limited value in burns, amputations, and in dark skin \\
\hline Capillary refill time & Cohort & $\begin{array}{l}\text { Index CRT: inter-rater variability } \\
\text { Knee CRT: limited value in dark skin }\end{array}$ \\
\hline PPI & Cohort & Needs an expensive device and electrodes \\
\hline $\mathrm{StO}_{2}$ & Cohort & $\begin{array}{l}\text { Needs NRIS and electrodes } \\
\text { Less accurate in septic shock } \\
\text { Less accurate in early shock stages }\end{array}$ \\
\hline $\mathrm{PtCO}_{2}$ & Cohort & $\begin{array}{l}\text { Needs special monitor and electrodes } \\
\text { No definitive cutoff value }\end{array}$ \\
\hline OCT & RCT & $\begin{array}{l}\text { Needs special monitor and electrodes } \\
\text { Restricted to intubated patients }\end{array}$ \\
\hline Sublingual microcirculation & Cohort & Needs special device \\
\hline
\end{tabular}

CRT capillary refill time, $L V$ left ventricular, NRIS near-infrared spectroscopy, OCT oxygen challenge test, Ptco ${ }_{2}$ subcutaneous partial oxygen pressure, PPI peripheral perfusion index, $\mathrm{P}(\mathrm{v}-\mathrm{a}) \mathrm{CO}_{2}$ central-venous-arterial oxygen gradient, $\mathrm{RCT}$ randomized controlled trial, $\mathrm{ScvO}_{2}$ central venous oxygen saturation, $\mathrm{StO}_{2}$ tissue oxygen saturation, $T_{c \text {-toe }}$ central-to-toe temperature gradient, $T_{\text {skin-diff }}$ temperature gradient between fingertip and forearm

\section{Selectivity and sensitivity in clinical settings}

Lactate is the most frequently used marker of tissue perfusion [6]. Lactic acidosis is a predictor of in-hospital mortality in septic shock $[7,8]$. Increased lactate clearance during resuscitation of septic shock was associated with improved outcomes [9].

\section{Usefulness in other settings}

Lactic acidosis is a predictor of in-hospital mortality in trauma [10] and cardiac arrest [11].

\section{Degree of invasiveness}

It is minimally invasive but needs available blood gas analysis.

\section{Mixed and central venous oxygen saturation Background}

Mixed venous oxygen saturation $\left(\mathrm{SvO}_{2}\right)$ is an indicator for adequate oxygen delivery $\left(\mathrm{DO}_{2}\right)[1]$; thus, the change in $\mathrm{SvO}_{2}$ reflects the change in cardiac output as long as other determinants of $\mathrm{DO}_{2}$ are stable [1]. In healthy individuals, $\mathrm{SvO}_{2}$ value is $75 \%$ while in critically ill patients, its value is $70 \%$ [1]. Central venous oxygen saturation $\left(\mathrm{ScvO}_{2}\right)$ is another indicator for oxygen delivery; however, the evidence on the correlation between $\mathrm{ScvO}_{2}$ and $\mathrm{SvO}_{2}$ is not clear $[12,13] . \mathrm{ScvO}_{2}$ reflects perfusion status in the upper body and is not affected by blood coming from the lower body nor coronary sinus [14]. In healthy individuals, $\mathrm{ScvO}_{2}$ is lower than $\mathrm{SvO}_{2}$ [15]; however, in shocked patients, $\mathrm{ScvO}_{2}$ may exceed $\mathrm{SvO}_{2}$ by up to $20 \%$ due to redistribution of blood to the upper body [16, 17].

\section{Selectivity and sensitivity in clinical settings}

Although $\mathrm{ScvO}_{2}$ and $\mathrm{SvO}_{2}$ are not interchangeable, $\mathrm{ScvO}_{2}$ is still useful as a predictor of outcome in septic shock. Persistently low $\mathrm{ScvO}_{2}$ during resuscitation is associated with poor outcomes in septic shock patients $[18,19]$. Despite its clinical value, maintenance of $\mathrm{ScvO}_{2}$ is no longer a resuscitation goal in the new surviving sepsis campaign guidelines [4].

\section{Usefulness in other settings}

Despite the limited value of $\mathrm{ScvO}_{2}$ under general anesthesia, it was reported as a valuable measure in cardiac surgery patients where lower $\mathrm{ScvO}_{2}$ values were associated with more complications [20]; moreover, in a randomized controlled trial, maintenance of $\mathrm{ScvO}_{2}$ of at least $70 \%$ was associated with lower complications in cardiac surgery patients [21].

\section{Limitations and degree of invasiveness}

In addition to the need to central venous catheter, $\mathrm{ScvO}_{2}$ is usually less informative under general anesthesia because the use of neuromuscular blockers decreases 
oxygen consumption; moreover, the use of high fraction of inspired oxygen usually $\left(\mathrm{FiO}_{2}\right)$ corrects hypoxemia and increases $\mathrm{DO}_{2}[22]$.

\section{$\mathrm{CO}_{2}$ gap $\left(\mathrm{P}(\mathrm{v}-\mathrm{a}) \mathrm{CO}_{2}\right)$ \\ Background}

The difference between $\mathrm{PCO}_{2}$ in central venous blood and $\mathrm{PCO}_{2}$ in arterial blood is known as central-venous-arterial $\mathrm{CO}_{2}$ gap ( $\mathrm{P}(\mathrm{v}-\mathrm{a}) \mathrm{CO}_{2}$ ). $\mathrm{P}(\mathrm{v}-\mathrm{a}) \mathrm{CO}_{2}$ has been considered as an indicator of the adequacy of venous blood flow to wash out $\mathrm{CO}_{2}$ in peripheral tissues [23]. Elevated P (v-a) $\mathrm{CO}_{2}$ (above $6 \mathrm{mmHg}$ ) occurs in cases of decreased systemic blood flow. Normalization of $\mathrm{P}(\mathrm{v}-\mathrm{a}) \mathrm{CO}_{2}$ during resuscitation was associated with normalization of serum lactate [24].

\section{Selectivity and sensitivity in clinical settings}

$\mathrm{P}$ (v-a) $\mathrm{CO}_{2}$ is negatively correlated with cardiac output in septic shock patients [25]; thus, $\mathrm{P}(\mathrm{v}-\mathrm{a}) \mathrm{CO}_{2}$ is a useful parameter to assess the adequacy of tissue perfusion during resuscitation of patients in septic shock [24]. Persistence of high $\mathrm{P}(\mathrm{v}-\mathrm{a}) \mathrm{CO}_{2}$ during early resuscitation of septic shock is associated with poor outcomes [26].

In cases with decreased $\mathrm{ScvO}_{2}$, a high P (v-a) $\mathrm{CO}_{2}$ denotes that tissue hypoperfusion is due to inadequate cardiac output, whereas normal $\mathrm{P}(\mathrm{v}-\mathrm{a}) \mathrm{CO}_{2}$ denotes that improving cardiac output is unlikely to improve the oxygen delivery to the tissues [23]. In cases of normal $\mathrm{ScvO}_{2}$ and $\mathrm{P}(\mathrm{v}-\mathrm{a}) \mathrm{CO}_{2}$ with evidence of anerobic metabolism (i.e., elevated serum lactate), manipulation of macrocirculation would be not effective to improve the condition because this denotes mitochondrial or microcirculatory disturbances [23].

\section{Usefulness in other settings}

In addition to its value in septic shock patients, $\mathrm{P}(\mathrm{v}-\mathrm{a})$ $\mathrm{CO}_{2}$ is also negatively correlated with cardiac output in cardiogenic shock patients [27] and patients with severe isovolemic anemia [28].

\section{Limitations and degree of invasiveness}

Assessment of $\mathrm{P}(\mathrm{v}-\mathrm{a}) \mathrm{CO}_{2}$ needs the presence of both arterial and central venous lines.

\section{Left ventricular strain Background}

Left ventricular longitudinal strain (LVS) is defined as "the percentage distance shortening of the endocardium along its length" [29]. The traditional parameter for assessment of left ventricular function is ejection fraction; however, this parameter could be confounded by cardiac preload and heart rate; moreover, it is highly operator dependent; thus, LVS appears as a novel method for evaluation of systolic function that could help in early detection of myocardial ischemia [30].

\section{Selectivity and sensitivity in clinical settings}

In a prospective observational study [31], the ability of LVS as a measure for oxygen delivery was evaluated. LVS was associated with elevated serum lactate and low $\mathrm{ScvO}_{2}$ in patients with septic shock. The findings of the aforementioned study suggest that LVS could be a noninvasive surrogate for assessment of tissue perfusion.

\section{Usefulness in other settings}

There is no available evidence.

\section{Limitations and degree of invasiveness}

This parameter is limited by the need of an expert echocardiography operator [31]. A summary for global and local indices is provided in Table 1.

\section{Markers of local perfusion \\ Temperature values and gradients Background}

Skin temperature is a traditional sign of peripheral vasoconstriction. Critically ill patients with cold skin temperature have lower cardiac index, lower Svo2, and higher serum lactate compared to patients with warm skin temperature [32]. Temperature gradients are better subjective methods for assessment of peripheral perfusion $[33,34]$.

Central-to-toe temperature $\left(T_{\mathrm{c}-\text { toe }}\right)$ is the difference between central temperature measured at the tympanic membrane and temperature at the ventral surface of the big toe measured by a skin probe. $T_{\mathrm{c} \text {-toe }}$ gradient has been used as a measure of peripheral vasoconstriction; however, it has the disadvantage of being affected hypothermia as well as room temperature [34].

The temperature gradient between fingertip and fore$\operatorname{arm}\left(T_{\text {skin-diff }}\right)$ has also been reported as a marker of peripheral vasoconstriction. $T_{\text {skin-diff }}$ is the difference between the temperatures at the index and at the radial side of the forearm measured using two skin probes. $T_{\text {skin-diff }}$ has the advantage of not being affected by the ambient temperature because the change in ambient temperature affects both fingertip and forearm equally $[34,35]$.

\section{Selectivity and sensitivity in clinical settings}

$T_{\text {c-toe }}$ more than $7{ }^{\circ} \mathrm{C}$ and $T_{\text {skin-diff }}$ more than $0{ }^{\circ} \mathrm{C}$ are indicators for vasoconstriction [34]. $T_{\text {skin-diff }}$ more than 2 and $4{ }^{\circ} \mathrm{C}$ indicates the presence of intermediate and severe vasoconstriction respectively [35]. There is an association between $T_{\text {skin-diff }}$ and poor outcomes in abdominal surgery patients [35] and in patients with acute circulatory failure. 


\section{Usefulness in other settings}

The persistence of peripheral perfusion alterations after reversal of therapeutic hypothermia are associated with poor outcomes in cases of out-of-hospital arrest [36]. In cardiac surgery patients, the transition from peripheral vasoconstriction to vasodilatation (measured by skin surface gradient) is associated with shorter time to extubation after both normothermic and hypothermic cardiopulmonary bypass [37].

\section{Limitations and degree of invasiveness}

It is a non-invasive parameter. $T_{\text {c-toe }}$ is affected by hypothermia and room temperature.

\section{Skin mottling \\ Background}

Skin mottling is defined as "patchy skin discoloration." Skin mottling usually manifests around the knees and might extend to other sites of peripheral circulation such as fingers and ears [33]. Skin mottling is a result of heterogeneous small vessel vasoconstriction [38]. Skin mottling is an easily assessed sign of peripheral hypoperfusion [38].

\section{Selectivity and sensitivity in clinical settings}

A six-grade scoring system (ranging from 0 to 5 ) has been introduced by Ait-Oufella and colleagues depending on the extent of skin mottling around the knee [39]. Skin mottling score (SMS) ranges from 0: no mottling, 1: a coin sized mottling area at the knee center, 2: a mottling area that does not extend above the upper margin of knee cap, 3: a mottling area localized to the lower thigh, 4: a mottling area reaching the upper thigh below the groin fold, to 5: extensive mottling reaching above the groin fold [39]. SMS could be subjective estimate of the severity of peripheral hypoperfusion [39]. Higher SMS (scoring 4 to 5 ) was associated with poor patient outcome in general ICU population [40] and in patients with septic shock [41]. A good correlation was reported between changes in both mottling score and skin perfusion (assessed by laser Doppler) during resuscitation of septic shock patients [42]. Prolonged skin mottling more than $6 \mathrm{~h}$ was associated with ICU mortality independently from severity scoring systems [40].

\section{Usefulness in other settings}

There is no available evidence.

\section{Limitations and degree of invasiveness}

It is a non-invasive parameter. It has a limited value in burns, amputations, and in dark skin.

\section{Capillary refill time (CRT)}

Background

CRT is defined as "the time needed for skin's color to return to baseline on a finger's tip after application of blanching pressure" [33]. CRT can be clinically measured over the fingertip [35, 43] or over the knee area [43]. CRT is a measure of peripheral capillary blood flow [33].

\section{Selectivity and sensitivity in clinical settings}

CRT showed a good correlation with urinary output and serum lactate levels [43]. Prolonged CRT has been associated with poor outcomes in septic shock patients [43] and in non-selected critically ill patients [34] with a cutoff value that ranged between 2.5 and $5 \mathrm{~s}$. Normalization of CRT was associated with improved survival rate in septic shock patients [44].

\section{Usefulness in other settings}

Prolonged CRT has also been associated with poor outcomes in patients following abdominal surgery [35].

\section{Limitations and degree of invasiveness}

It is a non-invasive parameter. Index CRT has the disadvantage of inter-rater variability. Knee CRT has a limited value in dark skin.

\section{Peripheral perfusion index (PPI) Background}

PPI represents "the ratio between the pulsatile and nonpulsatile component of the light reaching the pulse oximeter" [45]. As the pulsatile (arterial) flow is the only portion affected with vasoconstriction and vasodilatation, PPI has been considered as a numerical non-invasive measure for peripheral perfusion. PPI decreases in states of hypoperfusion due to decreased pulsatile component with a constant non-pulsatile component of blood flow [45].

\section{Selectivity and sensitivity in clinical settings}

The change in PPI reflects the change in other measures of hypoperfusion such as temperature gradients [45], lactate, and $\mathrm{P}$ (v-a) $\mathrm{CO}_{2}$ [46]. In critically ill patients, PPI less than 1.4 is a marker of hypoperfusion [45]; also, PPI less than 0.6 is an independent factor for 30-day mortality [46]. In septic shock patients, PPI less than 0.3 predicted vasopressor therapy [47] and below 0.2 predicted mortality [48].

\section{Usefulness in other settings}

Persistent decrease in PPI is associated with poor outcome after therapeutic hypothermia for out-of-hospital arrest [36] and in major abdominal surgery patients [35]. 


\section{Limitations and degree of invasiveness}

PPI is a non-invasive measure; however, it needs a special pulse oximeter. PPI is characterized by high skewness [45] and high inter-individual variability [49]; thus, it is more useful in trend monitoring for follow-up rather than being used as a single measure [49].

\section{Tissue oxygen saturation $\left(\mathrm{StO}_{2}\right)$ Background}

$\mathrm{StO}_{2}$ is measured using near-infrared spectroscopy (NIRS) [6]. Measurement by $\mathrm{StO}_{2}$ is based on the difference in light absorption between oxy- and deoxyhemoglobins [50]. $\mathrm{StO}_{2}$ represents the hemoglobin oxygen saturation in the tissues [6]. The normal value for $\mathrm{StO}_{2}$ is $87 \%$ which represents the sum of arterial, venous, and capillary blood oxygen saturation [51]. The most common sites for measurement of $\mathrm{StO}_{2}$ are thenar and frontal. $\mathrm{StO}_{2}$ decreases in states of hypoperfusion and hypoxia [50].

\section{Selectivity and sensitivity in clinical settings}

Thenar $\mathrm{StO}_{2}$ decreases in situations of hypoperfusion according to shock severity [51, 52]. In trauma patients, thenar $\mathrm{StO}_{2}$ could discriminate patients in severe shock [51]. Low thenar $\mathrm{StO}_{2}$ during initial resuscitation of multiple trauma patients correlate with future development of multiple organ dysfunction [53].

\section{Usefulness in other settings}

$\mathrm{StO}_{2}$ could predict the need of blood transfusion in trauma patients [54]. In cardiac surgery, cerebral oxygenation below $50 \%$ predicted poor postoperative cognitive dysfunction [55]; moreover, cerebral oxygenation showed good correlation with jugular venous saturation [56].

\section{Limitations and degree of invasiveness}

$\mathrm{StO}_{2}$ is a non-invasive parameter; however, it has some limitations: firstly, $\mathrm{StO}_{2}$ showed high variability among healthy volunteers, patients with mild and moderate shock; thus, its value is restricted to patients with severe shock [51]; secondly, this high variability makes $\mathrm{StO}_{2}$ a useful parameter for trend monitoring rather than a single measure value [49]. Thirdly, $\mathrm{StO}_{2}$ is of low value in patients with septic shock $[6,57]$.

\section{Continuous transcutaneous oxygen measurement Background}

Subcutaneous partial oxygen pressure $\left(\mathrm{PtCO}_{2}\right)$ was previously measured using invasive subcutaneous probes [58]; however, newer technology facilitated $\mathrm{Ptco}_{2}$ measurement using non-invasive transcutaneous probes $[59,60]$. $\mathrm{PtcO}_{2}$ has been more popular in neonates than adults [61]. The limited use of $\mathrm{Ptco}_{2}$ in adults is because of the lack of agreement between its value and arterial oxygen tension due to the thicker epidermis in adults compared to neonates [61].

\section{Selectivity and sensitivity in clinical settings}

Despite its low accuracy in adults, $\mathrm{Ptco}_{2}$ has been reported as a useful predictor for outcomes in critically ill emergency patients $[59,60]$. A newer parameter, the oxygen challenge test (OCT), was reported as a tool for early diagnosis of poor peripheral perfusion [48, 62, 63]. OCT the $\mathrm{Ptco}_{2}$ response to increasing $\mathrm{Fio}_{2}$ to 1 for a 5-min duration. The $\mathrm{Ptco}_{2}$ increased with increasing $\mathrm{FiO}_{2}$ in non-shocked patients, whereas $\mathrm{Ptco}_{2}$ poorly responded to increasing $\mathrm{FiO}_{2}$ in shocked patients. An increase of $21 \mathrm{mmHg}$ in $\mathrm{Ptco}_{2}$ after OCT was associated with better patient outcome [62]. Poor response to OCT was a predictor of mortality when reported before [62, 63] or after [48] resuscitation. In a randomized controlled trial, $\mathrm{Hu}$ et al. [64] investigated the use of OCT as a resuscitation target in patients with severe sepsis; they reported that a response of $25 \mathrm{mmHg}$ or more to OCT would improve the patient outcome.

\section{Usefulness in other settings}

There is no available evidence.

\section{Limitations and degree of invasiveness}

Although it is a non-invasive measure, $\mathrm{Ptco}_{2}$ has some limitations. $\mathrm{PtCO}_{2}$ needs special monitor and electrodes. Moreover, there is no definitive cutoff value. The value of OCT is restricted to intubated patients only.

\section{Sublingual microcirculation \\ Background}

Visualization of sublingual microcirculation using handheld microscopes has recently gained widespread attention. Direct visualization of microcirculation focuses on vascular density, flow, and proportion of perfused vessels [65]. Assessment of microcirculation has been a research tool not applicable in the clinical bedside assessment. With the introduction of more advanced microscopes (CytoCam), bedside real-time assessment of microcirculation has been available with adequate agreement with the conventional image analysis [66].

In a cross-sectional multicenter observational study, Lima et al. [67] investigated the inter-rater reliability for 45 physicians and 16 nurses in subjective assessment of sublingual microcirculation; participants were asked to categorize the videos into good, bad, and very bad microcirculation. Results of the aforementioned study showed good agreement between the participant assessment and the conventional analysis [67]. A recent protocol for real-time assessment of microcirculation was recently introduced by Naumann et al. [68]. Point of care microcirculation (POEM) is a 5-point scoring system that 
could be used for assessment of flow and heterogeneity with accepted inter-rater agreement [68].

\section{Selectivity and sensitivity in clinical settings}

It is still under research.

\section{Usefulness in other settings}

There is no available evidence.

\section{Limitations and degree of invasiveness}

Assessment of sublingual microcirculation is a noninvasive procedure. However, it has the disadvantage of the need of an expensive device.

\section{Perfusion-guided resuscitation}

Although normalization of central indices of tissue perfusion (such as lactate and $\mathrm{ScvO}_{2}$ ) has been an essential target of resuscitation of patients with septic shock [69], studies validating the value of targeting an improved peripheral perfusion markers are sparse. In an observational study, Hernandez and colleagues reported that early recovery of peripheral perfusion indices (such CRT, $T_{\text {c-toe }}$, and $\mathrm{P}\left(\mathrm{v}\right.$-a) $\mathrm{CO}_{2}$ ) is a marker of successful resuscitation of septic shock patients. In an animal study, Van Genderen et al. [70] reported a relationship between central and peripheral markers of perfusion during resuscitation of experimental shock; however, the rate of normalization of perfusion markers was dependent on the underlying type of shock. A randomized controlled trial (RCT) investigated the perfusion-based approach during resuscitation of 30 septic shock patients was conducted by the same group of authors [71]. The aforementioned study reported that the perfusion-based approach resulted in lower fluid replacement, less organ dysfunction, and shorter length of stay [71]. Larger RCTs are recommended to validate the perfusion-based approach and to set more clear steps of resuscitation.

\section{Conclusions}

Monitoring of tissue perfusion includes biomarkers of global tissue perfusion, measures for assessment of perfusion in non-vital organs, and direct visualization of sublingual microcirculation.

Three main clinical implications for perfusion indices were reported. First, the presence of poor tissue perfusion in a shocked patient is usually associated with worse outcome. Second, persistently impaired perfusion despite adequate resuscitation is associated with worse outcome. Third, normalization of some perfusion indices (lactate and central venous oxygen saturation) has become one of the resuscitation targets in patients with septic shock.

Direct visualization of sublingual circulation represents a promising tool for evaluation of peripheral perfusion.
Simple and user-friendly protocols are being introduced to facilitate the use of sublingual circulation as a bedside tool for assessment of shocked patients.

Although the collective evidence shows the clear relation between impaired peripheral perfusion and mortality, the use of different perfusion indices as a resuscitation target was not adequately investigated. Most of the data concerning the perfusion indices are extracted from observational trials with a few number of randomized controlled trials.

\section{Abbreviations \\ CRT: Capillary refill time; $\mathrm{DO}_{2}$ : Oxygen delivery; ICU: Intensive care unit; LVS: Left ventricular strain; NIRS: Near-infrared spectroscopy; OCT: Oxygen challenge test; $\mathrm{P}(\mathrm{v}-\mathrm{a}) \mathrm{CO}_{2}$ : Central-venous-arterial $\mathrm{CO}_{2}$ gap; POEM: Point of care microcirculation; PPI: Peripheral perfusion index; $\mathrm{PtCO}_{2}$ : Subcutaneous partial oxygen pressure; RCT: Randomized controlled trial; $\mathrm{ScvO}_{2}$ : Central venous oxygen saturation; SMS: Skin mottling score; $\mathrm{StO}_{2}$ : Tissue oxygen saturation; $\mathrm{SvO}_{2}$ : Mixed venous oxygen saturation; $T_{\text {c-toe: }}$ Central-to-toe temperature; $T_{\text {skin-diff: }}$ The temperature gradient between fingertip and forearm}

\section{Acknowledgements}

We would like to thank Dr. Ahmed Shash professor and head of Department of Anesthesia and Critical Care Medicine, Cairo University for his continuous support.

Funding

This work was funded by Cairo University.

Availability of data and materials

Not applicable.

Authors' contributions

AH was responsible for writing the manuscript and collection of the data. AM was responsible for conception of the topic and revision of the manuscript. $\mathrm{HN}$ helped in writing and revising the manuscript. All authors read and approved the final manuscript.

Competing interests

The authors declare that they have no competing interests.

Consent for publication

Not applicable.

Ethics approval and consent to participate Not applicable.

\section{Publisher's Note}

Springer Nature remains neutral with regard to jurisdictional claims in published maps and institutional affiliations.

Received: 25 November 2016 Accepted: 7 March 2017

Published online: 14 March 2017

\section{References}

1. Vincent J-L, Pelosi P, Pearse R, Payen D, Perel A, Hoeft A, et al. Perioperative cardiovascular monitoring of high-risk patients: a consensus of 12. Crit Care. 2015;19(1):224

2. Lighthall GK, Singh S. Perioperative maintenance of tissue perfusion and cardiac output in cardiac surgery patients. Semin Cardiothorac Vasc Anesth. 2014;18(2):117-36.

3. Jozwiak M, Monnet X, Teboul J-L. Monitoring: from cardiac output monitoring to echocardiography. Curr Opin Crit Care. 2015;21(5):395-401.

4. Rhodes A, Evans LE, Alhazzani W, Levy MM, Antonelli M, Ferrer R, et al. Surviving sepsis campaign. Crit Care Med. 2017;45(3):486-552.

5. Fuller BM, Dellinger RP. Lactate as a hemodynamic marker in the critically ill. Curr Opin Crit Care. 2012;18(3):267-72. 
6. Mayer K, Trzeciak S, Puri NK. Assessment of the adequacy of oxygen delivery Curr Opin Crit Care. 2016;22:437-43.

7. Mikkelsen ME, Miltiades AN, Gaieski DF, Goyal M, Fuchs BD, Shah CV, et al. Serum lactate is associated with mortality in severe sepsis independent of organ failure and shock. Crit Care Med. 2009;37(5):1670-7.

8. Trzeciak S, Dellinger RP, Chansky ME, Arnold RC, Schorr C, Milcarek B, et al. Serum lactate as a predictor of mortality in patients with infection. Intensive Care Med. 2007;33(6):970-7.

9. Nguyen $H B$, Rivers EP, Knoblich BP, Jacobsen G, Muzzin A, Ressler JA, et al. Early lactate clearance is associated with improved outcome in severe sepsis and septic shock. Crit Care Med. 2004;32(8):1637-42.

10. Abramson D, Scalea TM, Hitchcock R, Trooskin SZ, Henry SM, Greenspan J. Lactate clearance and survival following injury. J Trauma. 1993;35(4):584-8. discussion 588-9.

11. Kliegel A, Losert H, Sterz F, Holzer M, Zeiner A, Havel C, et al. Serial lactate determinations for prediction of outcome after cardiac arrest. Medicine (Baltimore). 2004;83(5):274-9.

12. Chawla LS, Zia H, Gutierrez G, Katz NM, Seneff MG, Shah M. Lack of equivalence between central and mixed venous oxygen saturation. Chest. 2004;126(6):1891-6.

13. Dueck MH, Klimek M, Appenrodt S, Weigand C, Boerner U. Trends but not individual values of central venous oxygen saturation agree with mixed venous oxygen saturation during varying hemodynamic conditions. Anesthesiology. 2005;103(2):249-57.

14. Glamann DB, Lange RA, Hillis LD. Incidence and significance of a \&quot; step-down\&quot; in oxygen saturation from superior vena cava to pulmonary artery. Am J Cardiol. 1991;68(6):695-7.

15. BARRATT-BOYES BG, WOOD EH. The oxygen saturation of blood in the venae cavae, right-heart chambers, and pulmonary vessels of healthy subjects. J Lab Clin Med. 1957;50(1):93-106.

16. Lee J, Wright F, Barber R, Stanley L. Central venous oxygen saturation in shock: a study in man. Anesthesiology. 1972;36(5):472-8.

17. Reinhart K, Rudolph T, Bredle DL, Hannemann L, Cain SM. Comparison of central-venous to mixed-venous oxygen saturation during changes in oxygen supply/demand. Chest. 1989;95(6):1216-21.

18. Pope JV, Jones AE, Gaieski DF, Arnold RC, Trzeciak S, Shapiro NI, et al. Multicenter study of central venous oxygen saturation $(\mathrm{ScvO}(2))$ as a predictor of mortality in patients with sepsis. Ann Emerg Med. 2010;55(1):40-6. e1.

19. Boulain T, Garot D, Vignon P, Lascarrou J-B, Desachy A, Botoc V, et al. Prevalence of low central venous oxygen saturation in the first hours of intensive care unit admission and associated mortality in septic shock patients: a prospective multicentre study. Crit Care. 2014;18(6):609.

20. Collaborative Study Group on Perioperative ScvO2 Monitoring. Multicentre study on peri- and postoperative central venous oxygen saturation in high-risk surgical patients. Crit Care. 2006;10(6):R158.

21. Pölönen P, Ruokonen E, Hippeläinen M, Pöyhönen M, Takala J. A prospective, randomized study of goal-oriented hemodynamic therapy in cardiac surgical patients. Anesth Analg. 2000;90(5):1052-9.

22. Van der Linden P, Schmartz D, Gilbart E, Engelman E, Vincent JL. Effects of propofol, etomidate, and pentobarbital on critical oxygen delivery. Crit Care Med. 2000;28(7):2492-9.

23. Mallat J, Lemyze M, Tronchon L, Vallet B, Thevenin D. Use of venous-toarterial carbon dioxide tension difference to guide resuscitation therapy in septic shock. World J Crit care Med. 2016;5(1):47-56.

24. Mallat J, Pepy F, Lemyze M, Gasan G, Vangrunderbeeck N, Tronchon L, et al. Central venous-to-arterial carbon dioxide partial pressure difference in early resuscitation from septic shock: a prospective observational study. Eur J Anaesthesiol. 2014;31(7):371-80.

25. Bakker J, Vincent JL, Gris P, Leon M, Coffernils M, Kahn RJ. Veno-arterial carbon dioxide gradient in human septic shock. Chest. 1992;101(2):509-15.

26. Ospina-Tascón GA, Bautista-Rincón DF, Umaña M, Tafur JD, Gutiérrez A, García AF, et al. Persistently high venous-to-arterial carbon dioxide differences during early resuscitation are associated with poor outcomes in septic shock. Crit Care. 2013;17(6):R294

27. Teboul JL, Mercat A, Lenique F, Berton C. Value of the venous-arterial PCO2 gradient to reflect the oxygen supply to demand in humans: effects of dobutamine. Crit Care Med. 1998;26(6):1007-10.

28. Kocsi S, Demeter G, Érces D, Kaszaki J, Molnár Z. Central venous-to-arterial CO2-gap may increase in severe isovolemic anemia. PLoS One. 2014;9(8):e105148.

29. Voigt J-U, Exner B, Schmiedehausen K, Huchzermeyer C, Reulbach U, Nixdorff $U$, et al. Strain-rate imaging during dobutamine stress echocardiography provides objective evidence of inducible ischemia. Circulation. 2003;107(16):2120-6.

30. Hoit BD. Strain and strain rate echocardiography and coronary artery disease. Circ Cardiovasc Imaging. 2011:4(2):179-90.

31. Lanspa MJ, Pittman JE, Hirshberg EL, Wilson EL, Olsen T, Brown SM, et al. Association of left ventricular longitudinal strain with central venous oxygen saturation and serum lactate in patients with early severe sepsis and septic shock. Crit Care. 2015;19:304.

32. Kaplan LJ, McPartland K, Santora TA, Trooskin SZ. Start with a subjective assessment of skin temperature to identify hypoperfusion in intensive care unit patients. J Trauma. 2001;50(4):620-7. discussion 627-8.

33. Ait-Oufella H, Bakker J. Understanding clinical signs of poor tissue perfusion during septic shock. Intensive Care Med. 2016;42(12):2070-2072.

34. Lima A, Jansen TC, van Bommel J, Ince C, Bakker J. The prognostic value of the subjective assessment of peripheral perfusion in critically ill patients. Crit Care Med. 2009;37(3):934-8.

35. van Genderen ME, Paauwe J, de Jonge J, van der Valk RJP, Lima A, Bakker J, et al. Clinical assessment of peripheral perfusion to predict postoperative complications after major abdominal surgery early: a prospective observational study in adults. Crit Care. 2014;18(3):R114.

36. van Genderen ME, Lima A, Akkerhuis M, Bakker J, van Bommel J. Persistent peripheral and microcirculatory perfusion alterations after out-of-hospital cardiac arrest are associated with poor survival. Crit Care Med. 2012;40(8):2287-94.

37. Pezawas T, Rajek A, Plöchl W. Core and skin surface temperature course after normothermic and hypothermic cardiopulmonary bypass and its impact on extubation time. Eur J Anaesthesiol. 2007;24(1):20-5.

38. Lima A, Takala J. Clinical significance of monitoring perfusion in non-vital organs. Intensive Care Med. 2014;40(7):1052-4.

39. Ait-Oufella H, Lemoinne S, Boelle PY, Galbois A, Baudel JL, Lemant J, et al. Mottling score predicts survival in septic shock. Intensive Care Med. 2011;37(5):801-7.

40. Coudroy R, Jamet A, Frat JP, Veinstein A, Chatellier D, Goudet V, et al. Incidence and impact of skin mottling over the knee and its duration on outcome in critically ill patients. Intensive Care Med. 2015;41(3):452-9.

41. de Moura EB, Amorim FF, da Cruz Santana AN, Kanhouche G, de Souza Godoy LG, de Jesus AL, et al. Skin mottling score as a predictor of 28-day mortality in patients with septic shock. Intensive Care Med. 2016;42(3):479-80.

42. Ait-Oufella H, Bourcier S, Alves M, Galbois A, Baudel J-L, Margetis D, et al. Alteration of skin perfusion in mottling area during septic shock. Ann Intensive Care. 2013;3(1):31.

43. Ait-Oufella H, Bige N, Boelle PY, Pichereau C, Alves M, Bertinchamp R, et al. Capillary refill time exploration during septic shock. Intensive Care Med. 2014;40(7):958-64.

44. Hernandez G, Luengo C, Bruhn A, Kattan E, Friedman G, Ospina-Tascon G, et al. When to stop septic shock resuscitation: clues from a dynamic perfusion monitoring. Ann Intensive Care. 2014;4:30.

45. Lima AP, Beelen P, Bakker J. Use of a peripheral perfusion index derived from the pulse oximetry signal as a noninvasive indicator of perfusion. Crit Care Med. 2002;30(6):1210-3.

46. He H, Long Y, Liu D, Wang X, Zhou X. Clinical classification of tissue perfusion based on the central venous oxygen saturation and the peripheral perfusion index. Crit Care. 2015;19(1):330.

47. Rasmy I, Mohamed H, Nabil N, Abdalah S, Hasanin A, Eladawy A, et al. Evaluation of perfusion index as a predictor of vasopressor requirement in patients with severe sepsis. Shock. 2015;44(6):554-9.

48. He HW, Liu DW, Long Y, Wang XT. The peripheral perfusion index and transcutaneous oxygen challenge test are predictive of mortality in septic patients after resuscitation. Crit Care. 2013;17(3):R116.

49. Høiseth Lø, Hisdal J, Hoff IE, Hagen OA, Landsverk SA, Kirkebøen KA. Tissue oxygen saturation and finger perfusion index in central hypovolemia: influence of pain. Crit Care Med. 2015;43(4):747-56.

50. Landesberg G, Shamir M, Avidan A. Early noninvasive detection of hypovolemia in trauma patients - are we there Yet?*. Crit Care Med. 2015:43(4):907-8.

51. Crookes BA, Cohn SM, Bloch S, Amortegui J, Manning R, Li P, et al. Can near-infrared spectroscopy identify the severity of shock in trauma patients? J Trauma. 2005;58(4):806-13. discussion 813-6.

52. Mancini DM, Bolinger L, Li H, Kendrick K, Chance B, Wilson JR. Validation of near-infrared spectroscopy in humans. J Appl Physiol. 1994;77(6):2740-7.

53. Nicks BA, Campons KM, Bozeman WP. Association of low non-invasive nearinfrared spectroscopic measurements during initial trauma resuscitation 
with future development of multiple organ dysfunction. World J Emerg Med. 2015;6(2):105-10.

54. Smith J, Bricker S, Putnam B. Tissue oxygen saturation predicts the need for early blood transfusion in trauma patients. Am Surg. 2008;74(10):1006-11.

55. Slater JP, Guarino T, Stack J, Vinod K, Bustami RT, Brown 3rd JM, Rodriguez AL, Magovern CJ, Zaubler T, Freundlich KPG. Cerebral oxygen desaturation predicts cognitive decline and longer hospital stay after cardiac surgery. Ann Thorac Surg. 2009;87(1):36-44.

56. Daubeney PE, Pilkington SN, Janke E, Charlton GA, Smith DCWS. Cerebral oxygenation measured by near-infrared spectroscopy: comparison with jugular bulb oximetry. Ann Thorac Surg. 1996;61(3):930-4.

57. Macdonald SPJ, Brown SGA. Near-infrared spectroscopy in the assessment of suspected sepsis in the emergency department. Emerg Med J. 2015;32(5):404-8.

58. Waxman K, Annas C, Daughters K, Tominaga GT, Scannell G. A method to determine the adequacy of resuscitation using tissue oxygen monitoring. J Trauma. 1994;36(6):852-6. discussion 856-8.

59. Shoemaker WC, Wo CC, Chan L, Ramicone E, Kamel ES, Velmahos GC, et al. Outcome prediction of emergency patients by noninvasive hemodynamic monitoring. Chest. 2001;120(2):528-37.

60. Tatevossian RG, Wo CC, Velmahos GC, Demetriades D, Shoemaker WC. Transcutaneous oxygen and $\mathrm{CO} 2$ as early warning of tissue hypoxia and hemodynamic shock in critically ill emergency patients. Crit Care Med. 2000;28(7):2248-53.

61. Huch R, Huch A, Lübbers DW. Transcutaneous measurement of blood Po2 (tcPo2) - method and application in perinatal medicine. J Perinat Med. 1973;1(3):183-91.

62. Yu M, Morita SY, Daniel SR, Chapital A, Waxman K, Severino R. Transcutaneous pressure of oxygen: a noninvasive and early detector of peripheral shock and outcome. Shock. 2006;26(5):450-6.

63. He H-W, Liu D-W, Long Y, Wang X-T, Chai W-Z, Zhou X. The transcutaneous oxygen challenge test: a noninvasive method for detecting low cardiac output in septic patients. Shock. 2012;37(2):152-5.

64. Yu M, Chapital A, Ho HC, Wang J, Takanishi D. A prospective randomized trial comparing oxygen delivery versus transcutaneous pressure of oxygen values as resuscitative goals. Shock. 2007;27(6):615-22.

65. Lima A. Current status of tissue monitoring in the management of shock. Curr Opin Crit Care. 2016;22(3):274-8.

66. Tanaka S, Harrois A, Nicolaï C, Flores M, Hamada S, Vicaut E, et al. Qualitative real-time analysis by nurses of sublingual microcirculation in intensive care unit: the MICRONURSE study. Crit Care. 2015;19:388.

67. Lima A, López A, van Genderen ME, Hurtado FJ, Angulo M, Grignola JC, et al. Interrater reliability and diagnostic performance of subjective evaluation of sublingual microcirculation images by physicians and nurses: a multicenter observational study. Shock. 2015;44(3):239-44.

68. Naumann DN, Mellis C, Husheer SLG, Hopkins P, Bishop J, Midwinter MJ, et al. Real-time point of care microcirculatory assessment of shock: design, rationale and application of the point of care microcirculation (POEM) tool. Crit Care. 2016;20(1):310.

69. Dellinger RP, Levy MM, Rhodes A, Annane D, Gerlach H, Opal SM, et al. Surviving sepsis campaign: international guidelines for management of severe sepsis and septic shock: 2012. Crit Care Med. 2013;41(2):580-637.

70. van Genderen ME, Klijn E, Lima A, de Jonge J, Sleeswijk Visser S, Voorbeijtel $J$, et al. Microvascular perfusion as a target for fluid resuscitation in experimental circulatory shock. Crit Care Med. 2014;42(2):e96-105.

71. Pe M, Goad A, Thompson C, Taylor K, Harry B, Passmore L, et al. Early peripheral perfusion-guided fluid therapy in patients with septic Shock. Am J Respir Crit Care Med. 2015;191(4):477-80

\section{Submit your next manuscript to BioMed Central and we will help you at every step:}

- We accept pre-submission inquiries

- Our selector tool helps you to find the most relevant journal

- We provide round the clock customer support

- Convenient online submission

- Thorough peer review

- Inclusion in PubMed and all major indexing services

- Maximum visibility for your research

Submit your manuscript at www.biomedcentral.com/submit

) Biomed Central 